\title{
Light-absorbing secondary organic material formed by glyoxal in aqueous aerosol mimics
}

\author{
E. L. Shapiro, J. Szprengiel, N. Sareen, C. N. Jen, M. R. Giordano, and V. F. McNeill \\ Department of Chemical Engineering, Columbia University, New York, NY, 10027, USA
}

Received: 27 October 2008 - Published in Atmos. Chem. Phys. Discuss.: 5 January 2009

Revised: 23 March 2009 - Accepted: 23 March 2009 - Published: 1 April 2009

\begin{abstract}
Light-absorbing and high-molecular-weight secondary organic products were observed to result from the reaction of glyoxal in mildly acidic $(\mathrm{pH}=4)$ aqueous inorganic salt solutions mimicking aqueous tropospheric aerosol particles. High-molecular-weight $(500-600 \mathrm{amu})$ products were observed when ammonium sulfate $\left(\left(\mathrm{NH}_{4}\right)_{2} \mathrm{SO}_{4}\right)$ or sodium chloride $(\mathrm{NaCl})$ was present in the aqueous phase. The products formed in $\left(\mathrm{NH}_{4}\right)_{2} \mathrm{SO}_{4}$ or ammonium nitrate $\left(\mathrm{NH}_{4} \mathrm{NO}_{3}\right)$ solutions absorb light at UV and visible wavelengths. Substantial absorption at $300-400 \mathrm{~nm}$ develops within two hours, and absorption between 400-600 nm develops within days. Pendant drop tensiometry measurements show that the products are not surface-active. The experimental results along with ab initio predictions of the UV/Vis absorption of potential products suggest a mechanism involving the participation of the ammonium ion. If similar products are formed in atmospheric aerosol particles, they could change the optical properties of the seed aerosol over its lifetime.
\end{abstract}

\section{Introduction}

Although secondary organic aerosol (SOA) formation has been the subject of study for many years, recent field measurements have revealed significantly more SOA than predicted by state-of-the-art atmospheric chemistry models (Heald et al., 2005; Volkamer et al., 2006). This suggests the existence of SOA precursors or mechanisms which have not yet been identified, or pathways which are known but not currently represented well in models. For example, the abundant biogenic VOC isoprene was recently identified as a major SOA source which was previously not included in models (Heald et al., 2005; Henze and Seinfeld, 2006; Kroll

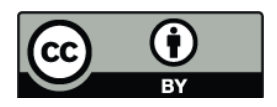

Correspondence to: V. F. McNeill (vfm2103@ columbia.edu) et al., 2006). It has also been suggested that SOA formation in urban areas from anthropogenic VOCs is underrepresented in models (Volkamer et al., 2006), and that the heterogeneous uptake of glyoxal (CHOCHO) by aerosols could be a significant source of unaccounted-for OA (Volkamer et al., 2007).

Glyoxal is a gas-phase oxidation product of many biogenic and anthropogenic VOCs (Tuazon et al., 1984, 1986, 2005; Volkamer et al., 2001, 2005; Baker et al., 2005). Volkamer et al. (2007) observed glyoxal concentrations in Mexico City which were significantly lower than expected based on model predictions. After testing three scenarios with their model, they concluded that the missing sink of glyoxal was most likely irreversible heterogeneous uptake to aqueous inorganic aerosols with a reactive uptake coefficient of $\gamma \approx 0.0037$. They linked this missing sink to the $15-25 \%$ of observed SOA mass which was unaccounted for by models during the same Mexico City case study (Volkamer et al., 2006). The irreversible uptake of glyoxal by cloud droplets followed by dehydration is another likely pathway for SOA formation (Ervens et al., 2004, 2008; Carlton et al., 2007; Fu et al., 2008).

Glyoxal uptake to laboratory-generated aerosols has been studied by several groups (Jang and Kamens, 2001; Kroll et al., 2005; Liggio et al., 2005a, b; Hastings et al., 2005; Loeffler et al., 2006; Corrigan et al., 2008; Volkamer et al., 2009; Galloway et al., 2008). It has been suggested that, for aqueous seed aerosols, uptake is followed by hydration and acetal oligomer formation (Jang and Kamens, 2001; Hastings et al., 2005; Liggio et al., 2005a; Loeffler et al., 2006; Tong et al., 2006; Kua et al., 2008; Galloway et al., 2008; Nozière et al., 2009a). Some groups suggest the oligomerization process is acid-catalyzed. However, other laboratory and field studies do not support this mechanism (Kroll et al., 2005; Loeffler et al., 2006; Peltier et al., 2007; Volkamer et al., 2007). Organosulfate products have also been reported (Liggio et al., 2005b; Surratt et al., 2007, 2008; Gomez-Gonzalez et al., 2008; Galloway et al., 2008). Galloway et al. (2008)

Published by Copernicus Publications on behalf of the European Geosciences Union. 
showed that the formation of glycolic acid sulfate from glyoxal in ammonium sulfate seed aerosols requires UV irradiation. Kinetics studies of alcohol sulfate esterification via the direct reaction of sulfuric acid with alcohols suggest that that pathway may be too slow to be significant in atmospheric aerosols (Minerath et al., 2008). Two recent studies also report the formation of carbon-nitrogen compounds by glyoxal when $\mathrm{NH}_{4}^{+}$is present in the aqueous phase (Galloway et al., 2008; Nozière et al., 2009a).

The terms "oligomer" and "humic-like substances" (HULIS) are both used in the literature to refer to moderately large ( $\sim 300-600 \mathrm{Da})$ organic molecules resulting from accretion reactions of smaller monomer species, and HULIS is sometimes also attributed with some additional properties of terrestrial humic or fulvic acid, such as aromaticity and light absorption (Graber and Rudich, 2006). There is evidence that HULIS are surface active (Facchini et al., 1999; Kiss et al., 2005; Salma et al., 2006), although it has also been suggested that aggregate phases formed by HULIS and other large organic molecules may scavenge organic material from the aerosol surface (Tabazadeh, 2005). Laboratory and field studies provide further evidence for gas-phase VOC oxidation as a source of HULIS and oligomeric material in continental aerosols, with glyoxal being a potential reaction intermediate (Kalberer et al., 2004; Gao et al., 2006; GomezGonzalez et al., 2008; Müller et al., 2008). There is evidence that oligomerization reactions enhance the gas-particle partitioning of glyoxal to aqueous aerosols (Volkamer et al., 2007, 2009; Corrigan et al., 2008; Ip et al., 2009).

Further laboratory studies are needed in order to evaluate the relative importance of glyoxal as a precursor of SOA material and HULIS in atmospheric aerosols, and how the uptake of glyoxal may affect the physical properties of the seed aerosol. To this end, we studied the formation of secondary organic products by glyoxal in mildly acidic $(\mathrm{pH}=4)$ aqueous inorganic salt mixtures. We used UV/Vis spectrophotometry, pendant drop tensiometry, and matrix-assisted laser desorption ionization mass spectrometry (MALDI-MS) to characterize the reaction products, and the kinetics of product formation were investigated. When ammonium sulfate $\left(\left(\mathrm{NH}_{4}\right)_{2} \mathrm{SO}_{4}\right)$ is present in the aqueous phase, we find evidence of high-molecular-weight (up to $600 \mathrm{amu}$ ) products, and the mixtures absorb light at UV and visible wavelengths $(300-600 \mathrm{~nm})$. If these products are formed in atmospheric aerosol particles, they could change the optical properties of the seed aerosol over a period of hours to days.

\section{Experimental}

\subsection{Sample preparation}

Sample solutions were prepared using commercially available chemicals (Fisher Scientific, VWR, Alfa Aesar) and ultrapure water (Millipore) in batches of $100 \mathrm{~mL}$ or $250 \mathrm{~mL}$.
With the goal of mimicking a range of conditions relevant to aqueous atmospheric aerosols to the extent possible in a bulk system, solutions were made to be saturated in the inorganic salt of interest $\left(\left(\mathrm{NH}_{4}\right)_{2} \mathrm{SO}_{4}, \mathrm{NaCl}, \mathrm{Na}_{2} \mathrm{SO}_{4}, \mathrm{NH}_{4} \mathrm{NO}_{3}\right)$ (Tang and Munkelwitz, 1994; Tang et al., 1997). Glyoxalcontaining solutions were prepared using $40 \mathrm{wt} \%$ aqueous glyoxal (Fisher Scientific). Solutions were initially composed of $3.11 \mathrm{M}\left(\mathrm{NH}_{4}\right)_{2} \mathrm{SO}_{4}, 5.1 \mathrm{M} \mathrm{NaCl}, 1.18 \mathrm{M} \mathrm{Na}_{2} \mathrm{SO}_{4}$, or $24 \mathrm{MNH}_{4} \mathrm{NO}_{3}$, and glyoxal concentrations ranging from $0 \mathrm{M}-2.21 \mathrm{M}$. In order to achieve a pH relevant to tropospheric aerosols (Keene et al., 1998, 2002, 2004; Keene and Savoie, 1998; Fridlind and Jacobson, 2000; Pszenny et al., 2004), dilute $\mathrm{HNO}_{3}$ was added to the prepared salt stock solution dropwise until the mixture read $\mathrm{pH}=4( \pm 1)$ when tested with $\mathrm{pH}$ paper. Since the aqueous glyoxal stock solution itself was mildly acidic, in many cases no additional $\mathrm{HNO}_{3}$ was necessary to achieve $\mathrm{pH} 4$. All solutions were stored in Pyrex vessels until analysis. The Pyrex reaction vessels are expected to provide some shielding from UV, but the samples were not otherwise protected from light, except in control experiments as described in the text.

\subsection{UV/VIS spectrophotometry}

UV/VIS absorption of the samples was characterized using an HP 8453 UV/Visible Spectrophotometer in the Columbia University Materials Research Science and Engineering Center (MRSEC) facility. A $10 \mathrm{~mm}$ open-top quartz cuvette (Agilent Technologies) was used in order to minimize interference below $200 \mathrm{~nm}$. All measurements were taken at room temperature and ambient pressure.

\subsection{MALDI-MS}

A Voyager-DE MALDI mass spectrometer was used in order to test for the presence of high-molecular-weight products. The MALDI-MS was used in positive ion mode at $25000 \mathrm{~V}$. 2.5-dihydroxybenzoic acid (DHB) was used to make the matrix for all solutions following Karas et al. (1993). Briefly, $1 \mathrm{mg}$ of DHB was added to $100 \mu \mathrm{L}$ of a 9:1 (v/v) water to ethanol mixture. $1 \mu \mathrm{L}$ each of the sample and matrix mixture were deposited on the target (i.e. on-spot mixing). The mixture was allowed to dry for ten minutes before analysis. Spectra of the matrix mixture alone were taken as a background reference.

\subsection{Surface tension measurements}

Pendant drop tensiometry (PDT) was used to measure surface tension. The PDT apparatus used in this study is similar to that described by Anastasiadis et al. (1987). Full experimental details are available in the supplementary material. 

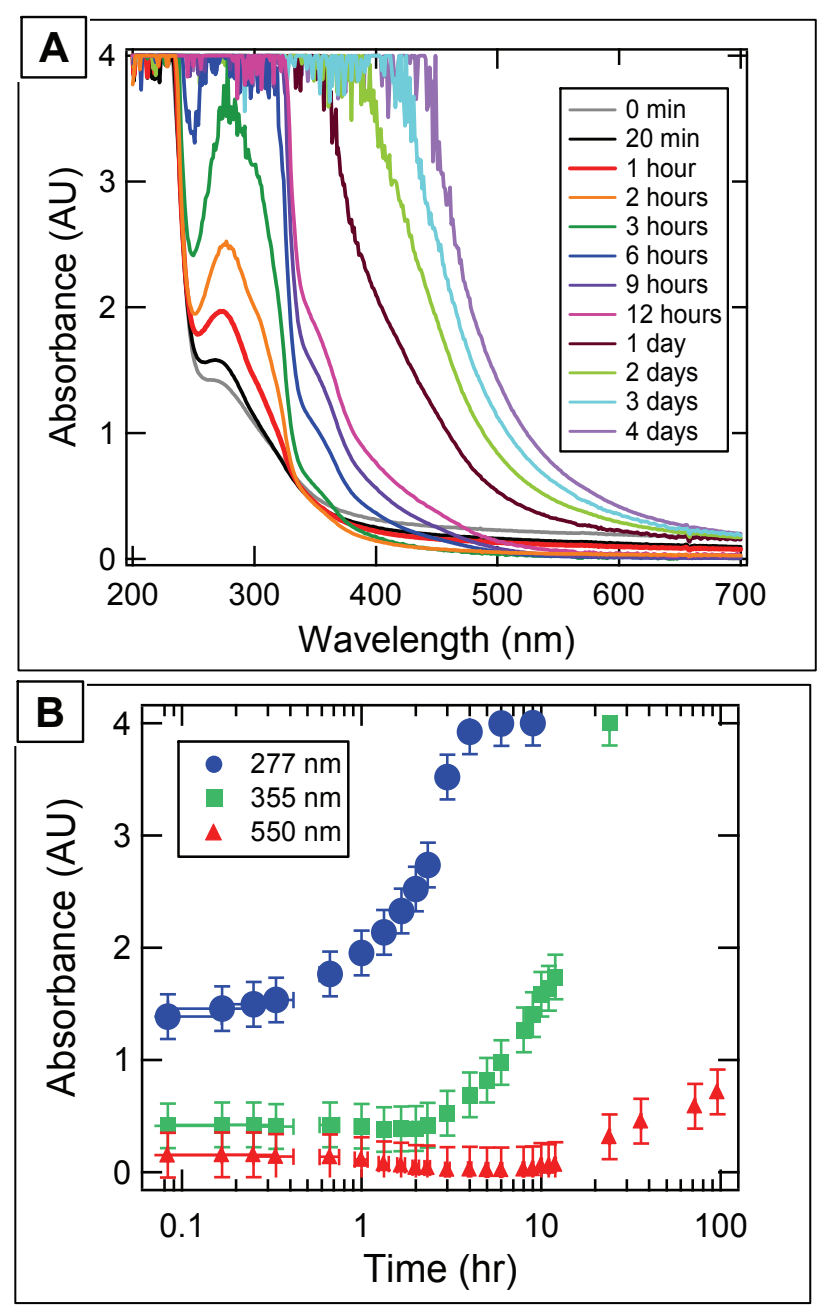

Fig. 1. Kinetics of product formation in an aqueous mixture containing $2.21 \mathrm{M}$ glyoxal and $3.1 \mathrm{M}\left(\mathrm{NH}_{4}\right)_{2} \mathrm{SO}_{4}(\mathrm{pH}=4)$. (a) Time series of UV/Vis spectra (b) Time dependence of absorption at $277 \mathrm{~nm}, 355 \mathrm{~nm}$, and $550 \mathrm{~nm}$.

\subsection{Ab initio calculations}

To aid in the interpretation of the UV/Vis spectrophotometry data, Jaguar 6.0 (Schrödinger, Inc.) was used for ab initio predictions of the UV/Vis absorption of potential products. Geometries were optimized and vibrational frequency calculations were performed using density functional theory (DFT) with the B3LYP functional and the cc-pVTZ(-f) basis set (Kendall et al., 1992). Configuration interaction singles (CIS) calculations were then used for the excited states, again with the cc-pVTZ(-f) basis set (Foresman et al., 1992). Calculations took minutes to hours when performed on an Intel Core 2 Duo 3.16 GHz PC.
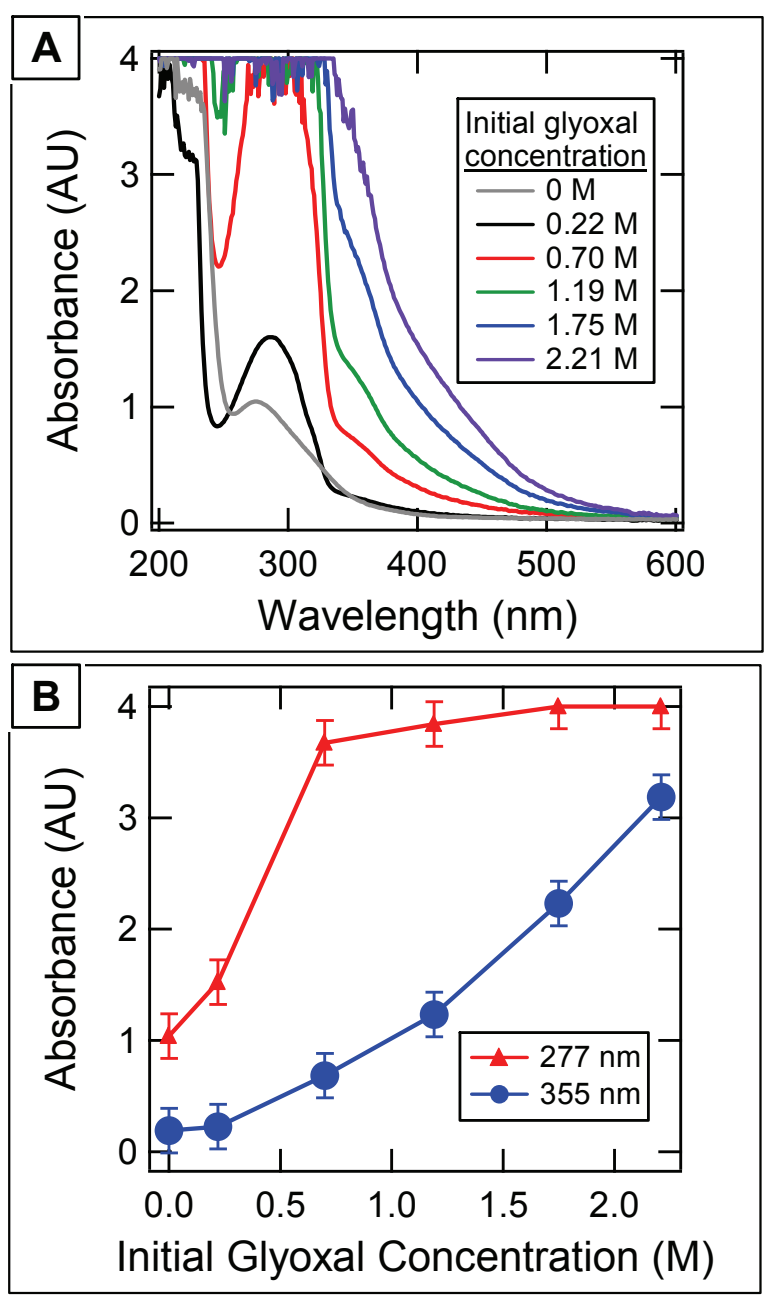

Fig. 2. Dependence of product formation on initial glyoxal concentration in an aqueous mixture containing $3.1 \mathrm{M}\left(\mathrm{NH}_{4}\right)_{2} \mathrm{SO}_{4}(\mathrm{pH}=4)$ (a) UV/Vis spectra $24 \mathrm{~h}$ after mixing (b) Initial glyoxal concentration dependence of absorption at $277 \mathrm{~nm}$ and $355 \mathrm{~nm}$ at $24 \mathrm{~h}$.

\section{Results}

All solutions containing $\left(\mathrm{NH}_{4}\right)_{2} \mathrm{SO}_{4}$ exhibited a color change visible to the naked eye within $\sim 1 \mathrm{~h}$ of preparation, with a final color of yellow to dark brown depending on the initial concentration of glyoxal in the mixture.

\subsection{UV/Vis absorption}

Using UV/Vis spectrophotometry we observed that products of the glyoxal- $\left(\mathrm{NH}_{4}\right)_{2} \mathrm{SO}_{4}$ interaction absorb light at $\mathrm{UV}$ and visible wavelengths (see Figs. 1 and 2). Figure 1a shows the time evolution of the UV spectrum of a solution initially containing $2.21 \mathrm{M}$ glyoxal over a period of 4 days. Absorbance at $277 \mathrm{~nm}$ is observed to increase linearly until the maximum absorbance measurable with this instrument is reached at $\sim 6 \mathrm{~h}$. A second peak at $355 \mathrm{~nm}$ develops and increases 


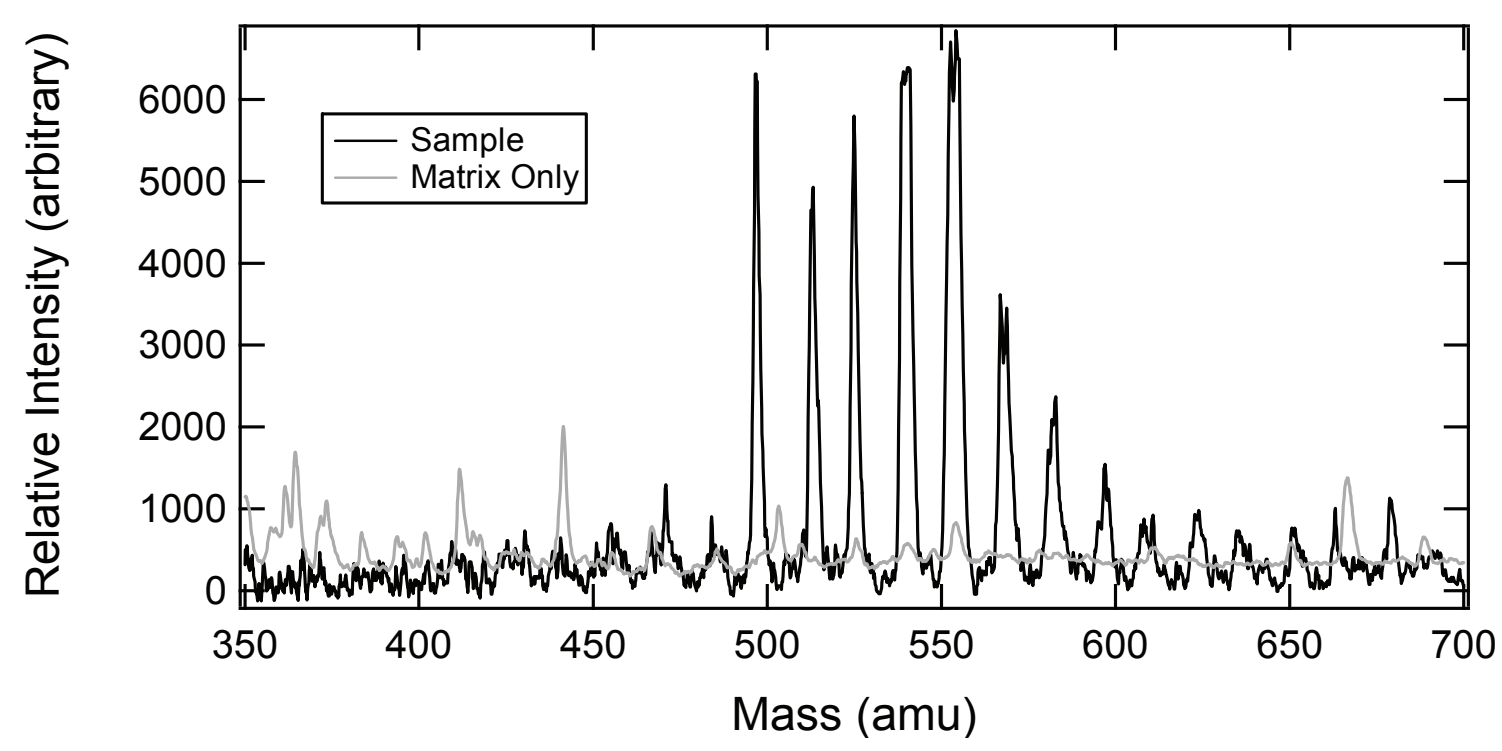

Fig. 3. MALDI-MS spectrum of the products of $2.21 \mathrm{M}$ glyoxal reacting in a mildly acidic (pH=4) aqueous mixture containing $3.1 \mathrm{M}$ $\left(\mathrm{NH}_{4}\right)_{2} \mathrm{SO}_{4}$. The measurement was made several days after mixing. Spectrum is also shown for the matrix only.

in magnitude between $6-12 \mathrm{~h}$. At $24 \mathrm{~h}$ the spectrum consists of a single broad absorption band that shifts to include longer wavelengths as time increases. Figure $1 \mathrm{~b}$ shows the absorbance of this solution at $277 \mathrm{~nm}, 355 \mathrm{~nm}$, and $550 \mathrm{~nm}$ as a function of time. The error bars shown reflect an uncertainty of $\pm 0.2 \mathrm{AU}$ in the measured absorbances based on variation observed in the baseline signal, perhaps due to fluctuations in the intensity of the lamp or the temperature in the instrument room.

Spectra shown in Fig. 2a were measured $24 \mathrm{~h}$ after each solution was prepared. Figure $2 \mathrm{~b}$ shows absorbance at $277 \mathrm{~nm}$ and $355 \mathrm{~nm}$ at $24 \mathrm{~h}$ as a function of initial glyoxal concentration. The peaks at 277 and $355 \mathrm{~nm}$ increase in magnitude and broaden with increasing initial glyoxal concentration, until at $2.21 \mathrm{M}$ the spectrum consists of a nearly featureless broad absorption band.

Control experiments were performed as follows: UV/Vis absorption spectra were obtained for 1) an aqueous glyoxal solution containing no salt, 2) an aqueous ammonium sulfate solution containing no glyoxal (see Fig. 2), 3) $2.21 \mathrm{M}$ glyoxal and $5.1 \mathrm{M} \mathrm{NaCl}(\mathrm{aq}), 4) 2.21 \mathrm{M}$ glyoxal and $1.18 \mathrm{M} \mathrm{Na}_{2} \mathrm{SO}_{4}$ (aq) and 5) $2.21 \mathrm{M}$ glyoxal and $24 \mathrm{M} \mathrm{NH}_{4} \mathrm{NO}_{3}$ (aq). Full results of the control experiments can be found in the supplementary material. Control samples (1)-(4) appeared clear to the naked eye and did not absorb significantly at wavelengths above $300 \mathrm{~nm}$. Glyoxal in aqueous solution has a weak, broad absorbance peak at $275 \mathrm{~nm}$ at ambient temperatures (Malik and Joens, 2000). The glyoxal/ammonium nitrate solution displayed a single broad absorption band extending to $330 \mathrm{~nm}$ after $24 \mathrm{~h}$, similar to the $2.21 \mathrm{M}$ glyoxal/ammonium sulfate solution. A sixth control experiment was also conducted wherein an aqueous solution of $2.21 \mathrm{M}$ glyoxal and
$3.11 \mathrm{M}\left(\mathrm{NH}_{4}\right)_{2} \mathrm{SO}_{4}$ was protected from ambient light by covering the Pyrex reaction vessel in aluminum foil until analysis. The UV/Vis absorption spectrum of this sample after $24 \mathrm{~h}$ of reaction closely resembles the equivalent $2.21 \mathrm{M}$ glyoxal curve in Fig. 2a, in which the sample was not protected from light during reaction. Slightly more absorption was observed in the $350-450 \mathrm{~nm}$ region for the solution that was protected from light.

\subsection{MALDI-MS}

MALDI-MS analysis of the products of glyoxal in mildly acidic aqueous $\left(\mathrm{NH}_{4}\right)_{2} \mathrm{SO}_{4}$ solution revealed the presence of high-molecular-weight organic material, consistent with an accretion reaction. Normalized MALDI mass spectra of the samples and the matrix (background) are shown in Fig. 3. Multiple peaks with signal $\geq 2 x$ the matrix background were present at mass-to-charge ratios ranging from $\sim 500-600$ amu. Control experiments were performed as follows: MALDI mass spectra were obtained for 1) an aqueous glyoxal solution containing no salt, 2) an aqueous ammonium sulfate solution containing no glyoxal and 3) an aqueous solution of $2.21 \mathrm{M}$ glyoxal and $5.1 \mathrm{M} \mathrm{NaCl}$. No peaks above the matrix background were present in the spectra for solutions 1) and 2). For solution 3) multiple signal peaks were observed at 500-600 amu. Most, but not all, of the peaks overlap with the glyoxal-ammonium sulfate sample spectrum. Full results of the control experiments can be found in the supplementary material. 


\subsection{Surface tension measurements}

The glyoxal/ammonium sulfate products were not observed to be surface active (see Fig. 4). Surface tension did not decrease with increasing glyoxal concentration compared to the surface tension of the pure ammonium sulfate solution.

\subsection{Irreversibility of product formation upon dehydration}

As a first-order test of whether the formation of the lightabsorbing products was reversible upon dehydration, a $5 \mathrm{~mL}$ sample of a solution initially containing $2.21 \mathrm{M}$ glyoxal and $3.11 \mathrm{M}\left(\mathrm{NH}_{4}\right)_{2} \mathrm{SO}_{4}$ was dehydrated overnight in a petri dish inside a vacuum oven at ambient temperature. A thick brown residue remained in the petri dish after dehydration, suggesting that product formation is irreversible over this time scale and under these conditions.

\section{Discussion}

Our observation of broad absorption at $300-600 \mathrm{~nm}$ as shown in Figs. 2 and 3 is similar to observations for HULIS or bulk WSOC isolated from atmospheric aerosols (Graber and Rudich, 2006; Hoffer et al., 2006). Field measurements have shown that the optical properties of ambient aerosols can change with photochemical aging (Moffet et al., 2008; Lyamani et al., 2008). Other groups have reported changes in the optical properties of reactive aerosol mimics over time (Nozière and Esteve, 2005, 2007; Nozière et al., 2007; Casale et al., 2007). Nozière et al. (2009a) reported an increase in the absorption at $209 \mathrm{~nm}$ with time for the aqueous glyoxal/ammonium sulfate system at lower glyoxal concentrations $(0.1 \mathrm{M})$ than those used in this study. They attributed the observed absorbance to a second-generation oligomerization product containing a $\mathrm{C}=\mathrm{N}$ or $\mathrm{C}=\mathrm{C}$ bond. The maximum concentration of glyoxal used in our study corresponds to $\sim 25 \mathrm{wt} \%$ organics in the solute; typical tropospheric aerosols contain 10-90 wt \% organic material (Kanakidou et al., 2005). It is possible that light-absorbing products such as those observed in this study are formed at the lower glyoxal concentrations used by Nozière et al. (2009a), but at quantities which were too small to detect. Alternatively, different products may be thermodynamically favored when the initial glyoxal concentration is high, as suggested by Barsanti and Pankow (2005).

Consistent with the recent results of Nozière et al. (2009a, b) and Galloway et al. (2008), our observation that lightabsorbing products form in the presence of ammonium sulfate and ammonium nitrate (but not $\mathrm{NaCl}$ or $\mathrm{Na}_{2} \mathrm{SO}_{4}$ ) suggests a mechanism involving the participation of the ammonium ion, and possibly a product or products containing $\mathrm{C}-\mathrm{N}$ bonds. The evolution of the UV spectra with increasing time and initial glyoxal concentration suggests that the chemical identity, not just the quantity, of the light-absorbing products

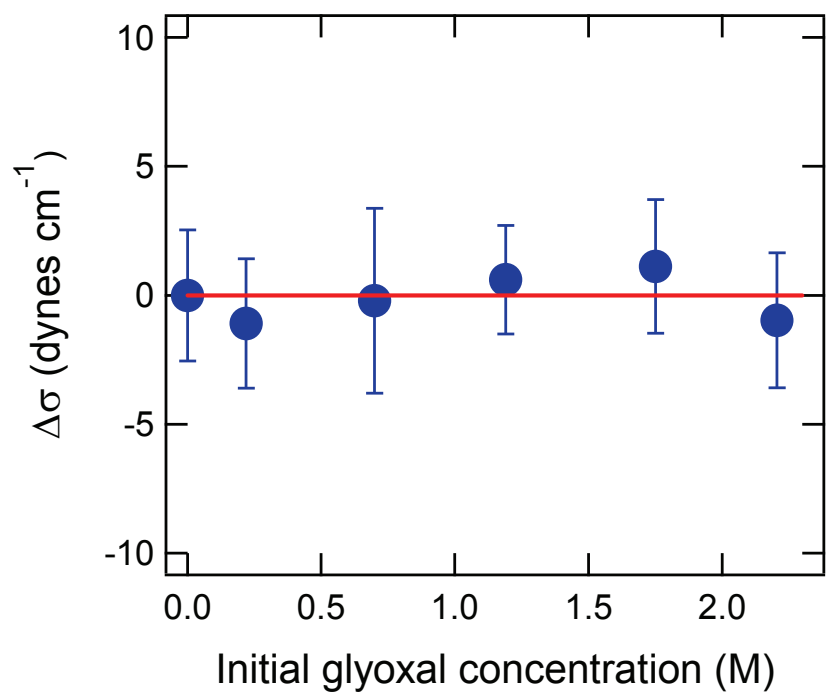

Fig. 4. The results of pendant drop tensiometry measurements of aqueous mixtures containing $3.1 \mathrm{M}\left(\mathrm{NH}_{4}\right)_{2} \mathrm{SO}_{4}(\mathrm{pH}=4)$ as a function of initial glyoxal concentration, expressed as deviation in surface tension from that of the $0 \mathrm{M}$ glyoxal solution. The measurements were made $24 \mathrm{~h}$ after mixing. Each point reflects the weighted average of three measurements, and the error bars represent the standard deviation in the raw data. The line at $\Delta \sigma=0$ is provided as a guide to the eye.

changed with these variables, consistent with multiple generations of products. Acetal oligomers (Liggio et al., 2005a, b; Loeffler et al., 2006; Tong et al., 2006; Kua et al., 2008; Galloway et al., 2008; Nozière et al., 2009a), organosulfates (Liggio et al., 2005b; Surratt et al., 2007, 2008; Galloway et al., 2008; Gomez-Gonzalez et al., 2008), and carbonnitrogen products (Galloway, et al., 2008; Nozière et al., 2009a) have been reported previously for glyoxal reacting in aqueous inorganic aerosols. Galloway et al. (2008) recently showed that irradiation was necessary for organosulfate formation in the glyoxal/ammonium sulfate system. This, together with the results of our control experiments, which demonstrate that light is not required for the light-absorbing reaction products to form in our system, suggests that it is not likely that the light-absorbing molecules in our system are organosulfate species. The mild acidity of our reaction mixtures reduces the probability of imidazole (Galloway et al., 2008) and iminium formation (Nozière et al., 2009a) as routes to $\mathrm{C}-\mathrm{N}$ bond formation, since both of these pathways require the participation of $\mathrm{NH}_{3}$ as a nucleophile. Nozière et al. (2009a) reported that the iminium pathway was active for glyoxal in ammonium-containing solutions down to $\mathrm{pH}$ 4.8 (the lowest $\mathrm{pH}$ studied), but that the second-order rate constant for this pathway increased with increasing $\mathrm{pH}$.

We performed ab initio simulations of the excited states of products previously reported in the literature for the glyoxal/ammonium sulfate system in order to evaluate them as potential contributors to our observed UV/Vis spectra. The 
Table 1. Results of ab initio predictions for UV/Vis absorption of glyoxal/ammonium sulfate products that have been proposed in the literature. Results are shown from CIS/cc-pvtz(-f) and DFT B3LYP/cc-pvtz(-f) simulations (see text for details). The energy and corresponding wavelength of transitions with oscillator strength $f>0.1$ are shown for the CIS simulations, and the energy of the HOMO-LUMO transition is shown for the DFT calculations. None of these molecules are predicted to absorb strongly at UV/Vis wavelengths. References are indicated by: 1) Liggio et al., 2005b 2) Surratt et al., 2007 3) Jang and Kamens, 2001 4) Liggio et al., 2005a 5) Loeffler et al., 2006 6) Tong et al., 2006 7) Hastings et al., 2005 8) Nozière et al., 2009a 9) Galloway et al., 2008.

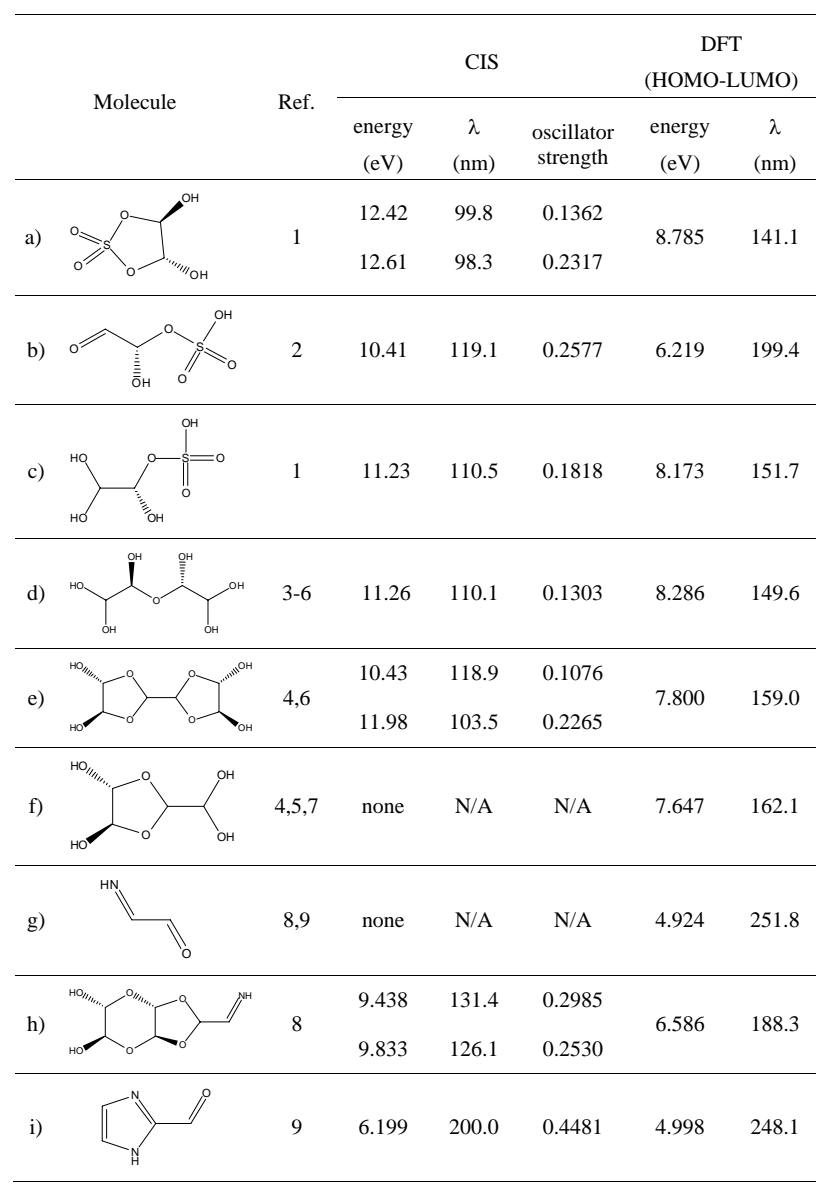

results are summarized in Table 1. The excitation energies calculated using CIS are typically biased high by $\sim 1 \mathrm{eV}$ compared to experimental values (Dorogan, 2008). Therefore the absorption wavelengths we calculate may be biased low by as much as $80 \mathrm{~nm}$, and correcting for this bias would improve agreement between the CIS and DFT results. Additional significant deviation between the theoretical results, which are for gas-phase molecules, and experiment may result from solvent effects. Both the CIS and DFT simulations of the molecules in Table 1 suggest that none of these species, if present in the solution, would absorb at visible
Table 2. Possible products for the glyoxal/ammonium sulfate system, and ab initio predictions of their UV/Vis absorption. The energy and corresponding wavelength of transitions with oscillator strength $f>0.1$ are shown from CIS/cc-pvtz(-f) simulations, and the energy and corresponding wavelength of the HOMO-LUMO transition is shown, based on DFT B3LYP/cc-pvtz(-f) calculations.

\begin{tabular}{|c|c|c|c|c|c|c|}
\hline & \multirow{2}{*}{ Molecule } & \multicolumn{3}{|c|}{ CIS } & \multicolumn{2}{|c|}{$\begin{array}{c}\text { DFT } \\
\text { (HOMO-LUMO) }\end{array}$} \\
\hline & & $\begin{array}{c}\text { energy } \\
(\mathrm{eV})\end{array}$ & $\begin{array}{c}\lambda \\
(\mathrm{nm})\end{array}$ & $\begin{array}{l}\text { oscillator } \\
\text { strength }\end{array}$ & $\begin{array}{c}\text { energy } \\
(\mathrm{eV})\end{array}$ & $\begin{array}{c}\lambda \\
(\mathrm{nm})\end{array}$ \\
\hline a) & & 5.583 & 222.1 & 1.1331 & 4.057 & 305.6 \\
\hline b) & & $\begin{array}{l}6.592 \\
5.559\end{array}$ & $\begin{array}{l}188.1 \\
223.0\end{array}$ & $\begin{array}{l}0.2552 \\
1.1016\end{array}$ & 4.108 & 301.8 \\
\hline c) & & 5.546 & 223.6 & 0.6557 & 2.663 & 465.6 \\
\hline d) & & 7.266 & 170.6 & 0.1775 & 5.676 & 218.5 \\
\hline \multirow{3}{*}{ e) } & & 7.803 & 158.9 & 1.7168 & 5.622 & 220.5 \\
\hline & & 10.218 & 121.4 & 0.1024 & \multirow{2}{*}{7.413} & \multirow{2}{*}{167.3} \\
\hline & & 10.276 & 120.6 & 0.1824 & & \\
\hline \multirow{2}{*}{ f) } & & 7.2183 & 171.8 & 0.8916 & \multirow{2}{*}{4.070} & \multirow{2}{*}{304.6} \\
\hline & & 7.0982 & 171.8 & 0.8058 & & \\
\hline
\end{tabular}

wavelengths. Therefore, while these products may exist in our solutions, it is not likely that they contribute to the observed absorption in the visible, and other products must be responsible.

Table 2 lists several molecules that were investigated as possible light-absorbing products, along with their predicted absorption energies and wavelengths. Pi-conjugated products are likely to absorb in the visible, so possible mechanisms which could result in their formation in this system were explored. Pi-conjugated products were reported by other groups to result from the acid-catalyzed aldol condensation reactions of aldehydes in aqueous aerosol mimics (Nozière et al., 2007; Nozière and Esteve, 2007; Casale et al., 2007). Glyoxal has been reported to be a retroaldol condensation product of glucose (Thornalley et al., 1999), however, glyoxal self-aldol condensation has not previously been reported. Molecules (a)-(c) in Table 2 are representative of the products that can be expected from an aldol condensation pathway involving glyoxal in the presence of ammonium sulfate. These pathways are most likely to initiate with the 
singly hydrated form of glyoxal or its imine analog (Galloway et al., 2008; Nozière et al., 2009a). In the enol form of singly hydrated glyoxal, the hydrated carbon is expected to be less reactive than the unhydrated carbon, resulting in the formation of carboxylic acid groups upon aldol addition. Therefore, the aldol condensation pathway may terminate at a 3-mer for glyoxal, with 3 possible isomers formed. The resulting dicarboxylic acid products (e.g. molecule (a) in Table 2) are predicted to absorb at $\lambda \sim 300 \mathrm{~nm}$, but they would not contribute to the observed MALDI mass spectrum. However, our DFT calculations suggest that addition at the hydrated carbon may be thermodynamically favorable for glyoxal with imine substitutions, which may occur when ammonium is present in aqueous solution (Galloway et al., 2008; Nozière et al., 2009a). The Gibbs free energy of the iminic acid intermediate leading to molecule (b) in Table 2 is $6.3 \mathrm{kcal} \mathrm{mol}^{-1}$ higher than that of the aldehyde-terminated intermediate that would result from aldol-type addition at the hydrated carbon (and would lead to molecule (c) after a second addition). This is in contrast to the glyoxal-only aldol condensation scheme, in which the carboxylic acid intermediate is $31 \mathrm{kcal} \mathrm{mol}^{-1}$ more stable than the aldehydeterminated intermediate. Subsequent additions to (c) would not necessarily result in termination by carboxylic or iminic acid groups and could lead to the formation of high molecular weight, light-absorbing species. In linear polyenes, the energy of the $\pi \rightarrow \pi^{*}$ transition will decrease with increasing chain length, resulting in higher absorption wavelengths for higher molecular weight species (Hudson and Kohler, 1974). Therefore, it is possible that conjugated oligomeric molecules of this type, if they form in this system, could be responsible for the absorption at $>400 \mathrm{~nm}$ observed at long times.

We also explored the possibility of imidazole polymer formation in our system, following Galloway et al. (2008). It was assumed that $1 \mathrm{H}$-imidazole-2-carboxaldehyde undergoes polymerization analogous to paraformaldehyde formation to create an acetal backbone (see molecule (d), Table 2). For this and the other long-chain polymers investigated, a relatively small molecule (in this case, $n=4$ imidazole monomers) was chosen in order to reduce the computational time required for the simulations. Despite the aromatic imidazole groups, the 4-mer was not predicted to absorb in the visible.

Other possible pathways for the formation of lightabsorbing products involve as intermediates the enol form of unhydrated glyoxal or its iminium analogs, which take the form of ketenes and ketimines, respectively. Ketenes have been suggested as reaction intermediates in SOA formation from toluene photooxidation (Hu et al., 2007). Ketenes have also been identified as precursors for glyoxal formation in the ozonolysis of acetylene (Cremer et al., 2001), suggesting that the formation of a ketene from glyoxal may be energetically uphill, but Vijay and Sastry (2005) found that a ketene was the most stable cationic isomer of glyoxal. Polymerization of glyoxal in the ketene form could occur via nucleophilic attack of the aldehyde carbon of one ketene by the $\mathrm{OH}$ group of another, resulting in oligomers such as molecule (e) in Table 2 (shown with its tautomer). Similarly, molecule (f) could be formed when $\mathrm{NH}_{4}^{+}$is present in aqueous solution. Molecule (e) and its tautomer are not predicted to absorb in the visible, but molecule (f) is.

MALDI-MS causes significant fragmentation (as evidenced by the matrix-only spectrum in Fig. 3), which makes it challenging to uniquely identify organic compounds using this technique. Nevertheless, it is clear that the observed peaks at $\sim 500-600 \mathrm{amu}$ correspond to parent molecules of a much greater molecular weight than the expected $\mathrm{m} / \mathrm{z}$ of products shown in Table 1 or their clusters with ammonium, sulfate, glyoxal, or water. This suggests that an accretion reaction is responsible for the observed peaks. Acetal oligomer formation has been commonly reported for glyoxal in aqueous systems (Fratzke and Reilly, 1986; Hastings et al., 2005; Liggio et al., 2005a; Loeffler et al., 2006; Galloway et al., 2008; Nozière et al., 2009a), with the highest masses (up to $\sim 475 \mathrm{amu}$ ) observed by Hastings et al. (2005) using electrospray ionization/ion trap mass spectrometry. A narrow chain length distribution is to be expected for polymerization reactions that follow an ionic mechanism, and average chain length is determined by the reaction kinetics (Rosen, 1993). Adjacent peaks in the MALDI spectra of both the glyoxal/ $\mathrm{NaCl}$ and glyoxal/ammonium sulfate solutions were separated by 14 amu on average. This separation is consistent with loss of a $-\mathrm{CH}_{2}$, or as may be the case in the $\left(\mathrm{NH}_{4}\right)_{2} \mathrm{SO}_{4}$ system, the difference between a $=\mathrm{NH}$ group and a hydrogen. It follows that nonadjacent peaks were separated roughly by multiples of $14 \mathrm{amu}$ : $28 \mathrm{amu}, 42 \mathrm{amu}, 56 \mathrm{amu}, 70 \mathrm{amu}$, 84 amu. A monomer unit in the case of an acetal oligomer (i.e. molecules (d)-(f) in Table 1) corresponds to 78-80 amu. In aldol condensation products such as molecules (a)-(c) in Table 2 , the monomer unit is $\sim 42 \mathrm{amu}$, for an imidazole polymer (i.e. molecule (d) in Table 2) it would be $95 \mathrm{amu}$, and for molecules (e) and (f) in Table 2 the monomer unit is 56-57 amu.

There are several possible explanations for our observation via MALDI of high-molecular-weight products in the glyoxal- $\mathrm{NaCl}$ solution, which were not strongly lightabsorbing, at similar masses to those observed in the glyoxalammonium sulfate solutions. The high-molecular-weight material in both systems could be acetal oligomers of similar structure, which we do not expect to absorb at visible wavelengths based on the results of our ab initio calculations. This would suggest that the light-absorbing products in the glyoxal-ammonium sulfate solutions are of lower molecular weight and were not detected via MALDI (e.g. species (a)(b) from Table 2). Another possibility is that, if the lightabsorbing products are of the type represented by molecule (f) in Table 2, the analog that would be formed in an $\mathrm{NaCl}$ solution would be molecule (e), which is expected to absorb at lower wavelengths. The mass of a carbonyl and $\mathrm{a}=\mathrm{NH}$ 
group (or a hydroxyl group and $-\mathrm{NH}_{2}$ ) differs by $1 \mathrm{amu}$, so these structures may not be readily distinguished via our MALDI spectra.

Strong acid catalysts such as sulfuric acid or methane sulfonic acid have been used to induce copolymer formation between glyoxal and DHB, the MALDI matrix compound used here, in an acetic acid environment (Tunca et al., 1995; Maravigna, 1988). One alternative interpretation of our observation of high-molecular-weight material in the glyoxal $/ \mathrm{NaCl}$ and glyoxal/ammonium sulfate samples via MALDI-MS is that a similar copolymerization mechanism could be active in our system, catalyzed by the presence of ions in the aqueous solution $\left(\mathrm{Na}^{+}, \mathrm{Cl}^{-}, \mathrm{NH}_{4}^{+}, \mathrm{SO}_{4}^{-2}\right)$. However, there is no evidence in the literature that ions of this type in a mildly acidic aqueous environment are sufficient to catalyze DHB-glyoxal copolymer formation, and the mass spectra themselves do not suggest DHB-glyoxal copolymers.

Based on the UV/Vis spectra of our reaction mixtures we anticipate that a complex mixture of light-absorbing products exists, and more than one product may contribute to the absorbance at a given wavelength. This, along with the likelihood of multiple competing reactions and multiple generations of products, complicates the analysis of the UV/Vis data. Therefore, in addition to standard reactionorder analysis, a kinetics model of a simplified reaction network was developed in order to further aid in the interpretation of the UV/Vis data. The model includes glyoxal reacting with itself to produce a dimer, or being processed by ammonium sulfate to produce a molecule "A" (e.g. iminium or organosulfate formation), and successive addition reactions between A and glyoxal to form molecules consisting of up to 3 monomer units. The full details of the model and the results of the simulation are given in the Supplementary Information. Since, to our knowledge, rate constant data are not available for each reaction in this system, all the rate constants were assumed to be equal. With each bimolecular rate constant set to a value of $5 \times 10^{-4} \mathrm{M}^{-1} \mathrm{~min}^{-1}$ the model roughly reproduced the time evolution of products observed in Fig. 1b. This rate constant is $\sim 100 x$ lower than that reported by Nozière et al. $(2009 \mathrm{a})\left(8( \pm 4) \times 10^{-4} \mathrm{M}^{-1} \mathrm{~s}^{-1}\right)$ for the evolution of an absorption peak at $209 \mathrm{~nm}$ in the aqueous glyoxal/( $\left(\mathrm{NH}_{4}\right)_{2} \mathrm{SO}_{4}$ system at low glyoxal concentrations. It is roughly 30x lower than the pseudo-first-order rate constant reported by Fratzke and Reilly (1986) for glyoxal dimerization at $\mathrm{pH} 5$ and $25^{\circ} \mathrm{C}\left(5 \times 10^{-4} \mathrm{~s}^{-1}\right)$.

The linear (first-order) dependence of the signal at $277 \mathrm{~nm}$ on initial glyoxal concentration for low concentrations (see Fig. $2 b$ ) is consistent with a product or products resulting from the direct reaction of glyoxal with ammonium sulfate. Its prompt evolution upon mixing (see Fig. 1b) is also consistent with a first-generation reaction product. An example of such a product is molecule $(\mathrm{g})$ in Table 1, imine-substituted glyoxal, which was predicted via DFT calculations to absorb at $252 \mathrm{~nm}$. Note that $1 \mathrm{H}$-imidazole-2-carboxaldehyde (molecule (i)) is predicted to absorb at similar wavelengths, although it is not a first-generation reaction product. The product or products absorbing at $355 \mathrm{~nm}$ exhibit a linear dependence on the square of the initial glyoxal concentration $\left(R^{2}=0.957\right)$ (i.e., second-order), consistent with glyoxal self-reaction or glyoxal reacting with the first-generation glyoxal/ $\left(\mathrm{NH}_{4}\right)_{2} \mathrm{SO}_{4}$ reaction product. However, the signal at $355 \mathrm{~nm}$ appears after a delay of roughly $3 \mathrm{~h}$, consistent with a second-generation product rather than glyoxal self-reaction. The imine-substituted aldol condensation dimer (i.e. precursor to molecule (c) in Table 2) is representative of this class of products. It is predicted to absorb at $336 \mathrm{~nm}$. The signals at $\lambda>500 \mathrm{~nm}$ appear after a delay of $\sim 12 \mathrm{~h}$, suggesting higher-order products. The existence of multiple products of unknown concentrations in this system makes it difficult to directly calculate the molar absorptivities, and thus rate constants, from the UV-Vis data. However, an upper bound can be derived by assuming that the maximum observed product concentration for a particular wavelength corresponds to the total initial glyoxal concentration. If we also assume that a single product absorbing at $277 \mathrm{~nm}$ is formed by the bimolecular reaction between glyoxal and ammonium sulfate and take the slope of the data in Fig. 1b or the linear portion of the curve in Fig. 2b, we estimate that $k<4.8 \times 10^{-4} \mathrm{M}^{-1} \mathrm{~min}^{-1}$. The rate constant that we used in the simplified reaction network model is consistent with this value.

While our control experiments demonstrate that light is not required for the formation of light-absorbing reaction products in this system, no conclusion can be drawn from these results as to whether or not they would form in the presence of UV irradiation. The Pyrex reaction vessels used in this study are opaque to $\lambda<280 \mathrm{~nm}$ (Corning, Inc.), and light transmission into the interior of the bulk solutions, given the strong absorbance in the UV and visible, was likely weak. Other groups have observed the formation of unique products, including oligomers, via the aqueous photoxidation of glyoxal (Carlton et al., 2007; Galloway et al., 2008) and other carbonyl-containing VOC oxidation products (Carlton et al., 2006; Guzman et al., 2006; Altieri et al., 2006, 2008).

Surface tension measurements provide an indirect method for detecting film formation at the interface, since the presence of an organic surface film will reduce the surface tension of an aqueous solution. Our observation that the glyoxal/ammonium sulfate products in this system are not surface-active distinguishes them from HULIS, which has been found by many groups to be surface-active (Kiss et al., 2005; Salma et al., 2006). One limitation of the pendant drop technique is the large sample volume required $(\sim 100 \mu \mathrm{l})$ relative to a typical aerosol particle volume. The high surface area-to-volume ratio of a submicron aerosol particle means that a greater fraction of the surfactant molecules will partition to the interface, raising the number of molecules that can be present before the critical micelle concentration is reached in the aerosol bulk (McNeill et al., 2006). Additionally, the small size of aerosol particles leads to supersaturated salt concentrations which are not accessible in this experiment 
(Tang et al., 1997; Tang, 1997; Tang and Munkelwitz, 1994). Increased salt concentration could lead to a "salting-out" effect and further surface partitioning of the organic material (Setschenow, 1889).

Aqueous-phase chemistry leading to the formation of light-absorbing organic species such as those observed in this study is a potential mechanism by which the absorption index of atmospheric aerosols may increase with aerosol age. Based on the data shown in Fig. 1 for solutions initially containing $2.21 \mathrm{M}$ glyoxal and $3.11 \mathrm{M}\left(\mathrm{NH}_{4}\right)_{2} \mathrm{SO}_{4}$ after 4 days, and assuming that the species absorbing at $\lambda>500 \mathrm{~nm}$ consist of at least 3 glyoxal monomer units, following Beer's law we obtain a lower-bound estimate of the molar absorptivity at $550 \mathrm{~nm}$ of $\varepsilon \geq 1 \mathrm{Lmol}^{-1} \mathrm{~cm}^{-1}$. Following the approach of Nozière et al. (2009a, b), the extinction coefficient of the solution at $550 \mathrm{~nm}$ is $\varepsilon_{550} \geq 0.71 \mathrm{~cm}^{-1}$ and the dimensionless absorption index, $A_{550}=\lambda \varepsilon_{550} / 4 \pi \geq 3.1 \times 10^{-6}$.

The chemistry observed here represents new potential pathways for SOA formation by glyoxal in aqueous aerosols. The atmospheric significance of these pathways will depend on the gas-aerosol mass transfer of glyoxal, which is the subject of active research. Glyoxal uptake to ammonium sulfate aerosols has been reported to follow Henry's law in aerosol chamber experiments, with $H_{\text {eff }} \sim 5 \times 10^{7} \mathrm{M} \mathrm{atm}^{-1}$ (Kroll et al., 2005; Galloway et al., 2008). Volkamer et al. (2007) inferred a higher value of $H_{\text {eff }} \sim 4 \times 10^{9} \mathrm{M} \mathrm{atm}^{-1}$ based on ambient glyoxal concentrations and SOA loadings in Mexico City, and found that the gas-particle partitioning of glyoxal could alternatively be modeled as irreversible uptake, with a reactive uptake coefficient of $\gamma \approx 0.0037$.

Assuming that Henry's law applies, we can calculate the reactive uptake coefficient, $\gamma$, for glyoxal following Hanson et al. (1994). A typical ammonium sulfate concentration in an aqueous atmospheric aerosol particle at $60 \% \mathrm{RH}$ is $\sim 65 \mathrm{wt} \%$ (Tang and Munkelwitz, 1994). Therefore, the pseudo-first-order loss coefficient for glyoxal due to the bimolecular reaction with ammonium sulfate in the aerosol phase will be $k^{I}<10^{-4} \mathrm{~s}^{-1}$. This value exceeds the aerosolphase pseudo-first-order loss coefficient reported by Nozière et al. (2009a) for $\mathrm{pH}=4$ by a factor of $\sim 140$. Using an estimated value of $1.6 \times 10^{-5} \mathrm{~cm}^{2} \mathrm{~s}^{-1}$ for the diffusion coefficient of glyoxal in the aerosol (Wilke and Chang, 1955), the reactive-diffusive length $l=\left(D / k^{I}\right)^{1 / 2}>0.4 \mathrm{~cm}$, much larger than the length scale of an aerosol particle. The reactive uptake coefficient is then given by (Hanson et al., 1994):

$\frac{1}{\gamma}=\frac{1}{\alpha}+\frac{\omega}{4 H T R\left(D k^{I}\right)^{1 / 2}} \frac{1}{[\operatorname{coth}(q)-1 / q]}$

where $\alpha$ is the mass accommodation coefficient, $\omega$ is the mean molecular speed of glyoxal, $H$ is the Henry's law coefficient, $T$ is the temperature, and $R$ is the gas constant. The diffuso-reactive parameter, $q$, is the ratio of the particle radius to $l$. For an aerosol particle with a radius of $200 \mathrm{~nm}$ at $298 \mathrm{~K}$, we find that $\gamma \sim 2 \times 10^{-14} H$ (where $H$ is in units of $\mathrm{M} \mathrm{atm}^{-1}$ ). Hence, the predicted reactive uptake coefficient based on the bimolecular reaction alone will be $\gamma \sim 10^{-6}$ if $H_{\text {eff }}=5 \times 10^{7} \mathrm{Matm}^{-1}$, or $\gamma \sim 8 \times 10^{-5}$ if $H_{\text {eff }}=4 \times 10^{9} \mathrm{M} \mathrm{atm}^{-1}$. This value will increase if other glyoxal reactions are included in the first order loss constant. If glyoxal uptake is effectively irreversible, as suggested by Volkamer et al. (2007), then the reactive uptake coefficient will not be directly dependent on the aqueous-phase kinetics.

\section{Conclusions}

We have observed the formation of light-absorbing and highmolecular-weight secondary organic products from the reaction of glyoxal in aqueous ammonium sulfate solutions at $\mathrm{pH}=4$. The experimental results along with ab initio predictions of the UV/Vis absorption of potential products suggest a mechanism involving participation of the ammonium ion and possibly a product or products containing $\mathrm{C}-\mathrm{N}$ bonds. If similar products are formed in atmospheric aerosol particles, they could change the optical properties of the seed aerosol over its lifetime. Aqueous oligomerization reactions of the type observed here may enhance the gas-particle partitioning of glyoxal to aqueous aerosols.

\section{Supplementary material available}

Details of the pendant drop apparatus and technique, UV/Vis and MALDI-MS spectra of the control solutions, and details of the polymerization kinetics model are available online in the supplementary material, see http://www.atmos-chem-phys.net/9/2289/2009/ acp-9-2289-2009-supplement.pdf.

Acknowledgements. The authors gratefully acknowledge the Ju group, especially L. Yu and J. Edwards, for assistance with the MALDI-MS, and the Koberstein group for use of the pendant drop tensiometer. We thank N. Chen for assistance with the image analysis software. We are also grateful to M. Steigerwald, B. Turpin, J. Sacher, and A. Schwier for helpful discussions, and to the reviewers of the discussion version of this manuscript for their insightful and constructive comments. This work was funded in part by a Columbia University Professional Schools Research Fellowship for VFM, and was partially supported by the Nanoscale Science and Engineering Initiative of the National Science Foundation under NSF Award Number CHE-0641523, and by the New York State Office of Science, Technology, and Academic Research (NYSTAR). E. L. S. and J. S. contributed equally to this work.

Edited by: J. Seinfeld

\section{References}

Anastasiadis, S. H., Chen, J. K., Koberstein, J. T., Siegel, A. F., Sohn, J. E., and Emerson, J. A.: The determination of interfacial tension by video image processing of pendant fluid drops, $\mathrm{J}$. Colloid Interf. Sci., 119(1), 55-66, 1987. 
Altieri, K. E., Carlton, A. G., Lim, H.-J., Turpin, B. J., and Seitzinger, S. P.: Evidence for oligomer formation in clouds: Reactions of isoprene oxidation products, Environ. Sci. Technol., 40, 4956-4960, 2006

Altieri, K. E., Seitzinger, S. P., Carlton, A. G., Turpin, B. J., Klein, G. C., and Marshall, A. G.: Oligomers formed through in-cloud methylglyoxal reactions: Chemical composition, properties, and mechanisms investigated by ultra-high resolution FT-ICR mass spectrometry, Atmos. Environ., 42, 1476-1490, 2008.

Badger, C. L., Griffiths, P. T., George, I., Abbatt, J. P. D., and Cox, R. A.: Reactive uptake of $\mathrm{N}_{2} \mathrm{O}_{5}$ by aerosol particles containing mixtures of humic acid and ammonium sulfate, J. Phys. Chem. A, 110(21), 6986-6994, 2006.

Baker, J., Arey, J., and Atkinson, R.: Formation and reaction of hydroxycarbonyls from the reaction of $\mathrm{OH}$ radicals with 1,3butadiene and isoprene, Environ. Sci. Technol., 39(11), 40914099, 2005.

Barsanti, K. C. and Pankow, J. F.: Thermodynamics of the formation of atmospheric organic particulate matter by accretion reactions - 2. Dialdehydes, methylglyoxal, and diketones, Atmos. Environ., 39(35), 6597-6607, 2005.

Carlton, A. G., Turpin, B. J., Lim, H.-J., Altieri, K. E., and Seitzinger, S.: Link between isoprene and secondary organic aerosol (SOA): Pyruvic acid oxidation yields low volatility organic acids in clouds, Geophys. Res. Lett., 33, L06822, doi:10.1029/2005GL025374, 2006.

Carlton, A. G., Turpin, B. J., Altieri, K. E., Seitzinger, S., Reff, A., Lim, H. J., and Ervens, B.: Atmospheric oxalic acid and SOA production from glyoxal: Results of aqueous photooxidation experiments, Atmos. Environ., 41(35), 7588-7602, 2007.

Casale, M. T., Richman, A. R., Elrod, M. J., Garland, R. M., Beaver, M. R., and Tolbert, M. A.: Kinetics of acid-catalyzed aldol condensation reactions of aliphatic aldehydes, Atmos. Environ., 41(29), 6212-6224, 2007.

Corrigan, A. L., Hanley, S. W., and De Haan, D. O.: Uptake of glyoxal by organic and inorganic aerosol, Environ. Sci. Technol., 42(12), 4428-4433, 2008.

Cremer, D., Crehuet, R., and Anglada, J.: The ozonolysis of acetylene: a quantum chemical investigation, J. Am. Chem. Soc., 123(25), 6127-6141, 2001.

Dorogan, I. V.: Theoretical Methods of Investigation of Excited States of Organic Molecules, Russ. J. Gen. Chem., 78(4), 774 783, 2008.

Ervens, B., Feingold, G., Frost, G. J., and Kreidenweis, S. M.: A modeling study of aqueous production of dicarboxylic acids: 1 . Chemical pathways and speciated organic mass production, J. Geophys. Res.-Atmos., 109(D15), doi:10.1029/2003JD004387, 2004.

Ervens, B., Carlton, A. G., Turpin, B. J., Altieri, K. E., Kreidenweis, S. M., and Feingold, G.: Secondary organic aerosol yields from cloud-processing of isoprene oxidation products, Geophys. Res. Lett., 35(2), L02816, doi:10.1029/2007GL031828, 2008.

Facchini, M. C., Mircea, M., Fuzzi, S., and Charlson, R. J.: Cloud albedo enhancement by surface-active organic solutes in growing droplets, Nature, 401(6750), 257-259, 1999.

Foresman, J. B., Head-Gordon, M., Pople, J. A., and Frisch, M. J.: Toward a systematic molecular orbital theory for excited states, J. Phys. Chem., 96, 135-149, 1992.

Fratzke, A. R. and Reilly, P. J.: Thermodynamic and Kinetic Analy- sis of the Dimerization of Aqueous Glyoxal, Int. J. Chem. Kinet., 18, 775-789, 1986.

Fridlind, A. M. and Jacobson, M. Z.: A study of gas-aerosol equilibrium and aerosol $\mathrm{pH}$ in the remote marine boundary layer during the First Aerosol Characterization Experiment (ACE 1), J. Geophys. Res.-Atmos., 105(D13), 17325-17340, 2000.

Fu, T.-M., Jacob, D. J., Wittrock, F., Burrows, J. P., Vrekoussis, M., and Henze, D. K.: Global budgets of atmospheric glyoxal and methylglyoxal, and implications for formation of secondary organic aerosols, J. Geophys. Res.-Atmos., 113, D15303, doi:10.1029/2007JD009505, 2008.

Galloway, M. M., Chhabra, P. S., Chan, A. W. H., Surratt, J. D., Flagan, R. C., Seinfeld, J. H., and Keutsch, F. N.: Glyoxal uptake on ammonium sulphate seed aerosol: reaction products and reversibility of uptake under dark and irradiated conditions, Atmos. Chem. Phys. Discuss., 8, 20799-20838, 2008, http://www.atmos-chem-phys-discuss.net/8/20799/2008/.

Gao, S., Surratt, J. D., Knipping, E. M., Edgerton, E. S., Shahgholi, M., and Seinfeld, J. H.: Characterization of polar organic components in fine aerosols in the southeastern United States: Identity, origin, and evolution, J. Geophys. Res.-Atmos., 111(D14), D14314, doi:10.1029/2005JD006601, 2006.

Gomez-Gonzalez, Y., Surratt, J. D., Cuyckens, F., Szmigielski, R., Vermeylen, R., Jaoui, M., Lewandowski, M., Offenberg, J. H., Kleindienst, T. E., Edney, E. O., Blockhuys, F., Van Alsenoy, C., Maenhaut, W., and Claeys, M.: Characterization of organosulfates from the photooxidation of isoprene and unsaturated fatty acids in ambient aerosol using liquid chromatography/(-) electrospray ionization mass spectrometry, J. Mass Spectrom., 43(3), 371-382, 2008.

Graber, E. R. and Rudich, Y.: Atmospheric HULIS: How humiclike are they? A comprehensive and critical review, Atmos. Chem. Phys., 6, 729-753, 2006, http://www.atmos-chem-phys.net/6/729/2006/.

Guzman, M. I., Colussi, A. J., and Hoffmann, M. R.: Photoinduced oligomerization of aqueous pyruvic acid, J. Phys. Chem. A, 110(10), 3619-3626, 2006.

Hanson, D. R., Ravishankara, A. R., and Solomon, S.: Heterogeneous reactions in sulphuric acid aerosols: A framework for model calculations, J. Geophys. Res., 99(D2), 3615-3629, 1994.

Hastings, W. P., Koehler, C. A., Bailey, E. L., and De Haan, D. O.: Secondary organic aerosol formation by glyoxal hydration and oligomer formation: Humidity effects and equilibrium shifts during analysis, Environ. Sci. Technol., 39(22), 8728-8735, 2005.

Heald, C. L., Jacob, D. J., Park, R. J., Russell, L. M., Huebert, B. J., Seinfeld, J. H., Liao, H., and Weber, R. J.: A large organic aerosol source in the free troposphere missing from current models, Geophys. Res. Lett., 32(18), L18809, doi:10.1029/2005GL023831, 2005.

Henze, D. K. and Seinfeld, J. H.: Global Secondary Organic Aerosol from Isoprene Oxidation, Geophys. Res. Lett., 33, L09812, doi:10.1029/2006GL025976, 2006.

Hoffer, A., Gelencsér, A., Guyon, P., Kiss, G., Schmid, O., Frank, G. P., Artaxo, P., and Andreae, M. O.: Optical properties of humic-like substances (HULIS) in biomass-burning aerosols, Atmos. Chem. Phys., 6, 3563-3570, 2006, http://www.atmos-chem-phys.net/6/3563/2006/.

Hu, D., Tolocka, M., Li, Q., and Kamens, R. M.: A kinetic mechanism for predicting secondary organic aerosol formation from 
toluene oxidation in the presence of $\mathrm{NO}_{\mathrm{x}}$ and natural sunlight, Atmos. Environ., 41, 6478-6496, 2007.

Hudson, B. and Kohler, B.: Linear Polyene Electronic Structure and Spectroscopy, Annu. Rev. Phys. Chem., 25, 437-460, 1974.

Ip, H. S. S., Huang, X. H. H., and Yu, J. Z.: Effective Henry's law constants of glyoxal, glyoxylic acid, and glycolic acid, Geophys. Res. Lett., 36, L01802, doi:10.1029/2008GL036212, 2009.

Jang, M. S. and Kamens, R. M.: Atmospheric secondary aerosol formation by heterogeneous reactions of aldehydes in the presence of a sulfuric acid aerosol catalyst, Environ. Sci. Technol., 35(24), 4758-4766, 2001.

Kalberer, M., Paulsen, D., Sax, M., Steinbacher, M., Dommen, J., Prevot, A. S. H., Fisseha, R., Weingartner, E., Frankevich, V., Zenobi, R., and Baltensperger, U.: Identification of polymers as major components of atmospheric organic aerosols, Science, 303, 5664, 1659-1662, 2004.

Kanakidou, M., Seinfeld, J. H., Pandis, S. N., Barnes, I., Dentener, F. J., Facchini, M. C., Van Dingenen, R., Ervens, B., Nenes, A., Nielsen, C. J., Swietlicki, E., Putaud, J. P., Balkanski, Y., Fuzzi, S., Horth, J., Moortgat, G. K., Winterhalter, R., Myhre, C. E. L., Tsigaridis, K., Vignati, E., Stephanou, E. G., and Wilson, J.: Organic aerosol and global climate modelling: a review, Atmos. Chem. Phys., 5, 1053-1123, 2005,

http://www.atmos-chem-phys.net/5/1053/2005/.

Karas, M., Ehring, H., Nordhoff, E., Stahl, B., Strupat, K., Hillenkamp, F., Grehl, M., and Krebs, B.: Matrix-Assisted LaserDesorption Ionization Mass-Spectrometry with Additives to 2,5Dihydroxybenzoic Acid, Org. Mass Spectrom., 28(12), 14761481, 1993.

Keene, W. C., Sander, R., Pszenny, A. A. P., Vogt, R., Crutzen, P. J., and Galloway, J. N.: Aerosol pH in the marine boundary layer: A review and model evaluation, J. Aerosol Sci., 29(3), 339-356, 1998.

Keene, W. C. and Savoie, D. L.: The $\mathrm{pH}$ of deliquesced seasalt aerosol in polluted marine air, Geophys. Res. Lett., 25(12), 2181-2184, 1998.

Keene, W. C., Pszenny, A. A. P., Maben, J. R., and Sander, R.: Variation of marine aerosol acidity with particle size, Geophys. Res. Lett., 29(7), 1101, doi:10.1029/2001GL013881, 2002.

Keene, W. C., Pszenny, A. A. P., Maben, J. R., Stevenson, E., and Wall, A.: Closure evaluation of size-resolved aerosol $\mathrm{pH}$ in the New England coastal atmosphere during summer, J. Geophys. Res.-Atmos., 109(D23), D23202, doi:10.1029/2004JD004801, 2004.

Kendall, R. A., Dunning, T. H., and Harrison, R. J.: Electron affinities of the first-row atoms revisited, Systematic basis sets and wave functions, J. Chem. Phys., 96(9), 6796-6806, 1992.

Kiss, G., Tombacz, E., and Hansson, H. C.: Surface tension effects of humic-like substances in the aqueous extract of tropospheric fine aerosol, J. Atmos. Chem., 50(3), 279-294, 2005.

Kroll, J. H., Ng, N. L., Murphy, S. M., Varutbangkul, V., Flagan, R. C., and Seinfeld, J. H.: Chamber studies of secondary organic aerosol growth by reactive uptake of simple carbonyl compounds, J. Geophys. Res.-Atmos., 110(D23), D23207, doi:10.1029/2005JD006004, 2005.

Kroll, J. H., Ng, N. L., Murphy, S. M., Flagan, R. C., and Seinfeld, J. H.: Secondary Organic Aerosol Formation from Isoprene Photoxidation, Environ. Sci. Technol., 40, 1869-1877, 2006.

Kua, J., Hanley, S. W., and De Haan, D. O.: Thermodynamics and kinetics of glyoxal dimer formation: A computational study, J. Phys. Chem. A, 112(1), 66-72, 2008.

Liggio, J., Li, S. M., and McLaren, R.: Reactive uptake of glyoxal by particulate matter, J. Geophys. Res.-Atmos., 110(D10), D10304, doi:10.1029/2004JD005113, 2005a.

Liggio, J., Li, S. M., and McLaren, R.: Heterogeneous reactions of glyoxal on particulate matter: Identification of acetals and sulfate esters, Environ. Sci. Technol., 39(6), 1532-1541, 2005b.

Loeffler, K. W., Koehler, C. A., Paul, N. M., and De Haan, D. O.: Oligomer formation in evaporating aqueous glyoxal and methyl glyoxal solutions, Environ. Sci. Technol., 40(20), 6318-6323, 2006.

Lyamani, H., Olmo, F. J., and Alados-Arboledas, L.: Light scattering and absorption properties of aerosol particles in the urban environment of Granada, Spain, Atmos. Environ., 42(11), 2630 2642, 2008.

Malik, M. and Joens, J. A.: Temperature dependent near-UV molar absorptivities of glyoxal and gluteraldehyde in aqueous solution, Spectrochim. Acta A, 56(14), 2653-2658, 2000.

Maravigna, P.: Thermally Stable Polymers by Condensation of Diphenols with Glyoxal, J. Polym. Sci. A, 26(9), 2475-2485, 1988.

McNeill, V. F., Patterson, J., Wolfe, G. M., and Thornton, J. A.: The effect of varying levels of surfactant on the reactive uptake of $\mathrm{N}_{2} \mathrm{O}_{5}$ to aqueous aerosol, Atmos. Chem. Phys., 6, 1635-1644, 2006, http://www.atmos-chem-phys.net/6/1635/2006/.

Minerath, E. C., Casale, M. T., and Elrod, M. J.: Kinetics feasibility study of alcohol sulfate esterification reactions in tropospheric aerosols, Environ. Sci. Technol., 42(12), 4410-4415, 2008.

Moffet, R. C., Qin, X. Y., Rebotier, T., Furutani, H., and Prather, K. A.: Chemically segregated optical and microphysical properties of ambient aerosols measured in a single-particle mass spectrometer, J. Geophys. Res.-Atmos., 113(D12), D12213, doi:10.1029/2007JD009393, 2008.

Müller, L., Reinnig, M.-C., Warnke, J., and Hoffmann, Th.: Unambiguous identification of esters as oligomers in secondary organic aerosol formed from cyclohexene and cyclohexene/ $\alpha$ pinene ozonolysis, Atmos. Chem. Phys., 8, 1423-1433, 2008, http://www.atmos-chem-phys.net/8/1423/2008/.

Nozière, B. and Esteve, W.: Organic reactions increasing the absorption index of atmospheric sulfuric acid aerosols, Geophys. Res. Lett., 32(3), L03812, doi:10.1029/2004GL021942, 2005.

Nozière, B. and Esteve, W.: Light-absorbing aldol condensation products in acidic aerosols: Spectra, kinetics, and contribution to the absorption index, Atmos. Environ., 41(6), 1150-1163, 2007.

Nozière, B., Dziedzic, P., and Cordova, A.: Formation of secondary light-absorbing "fulvic-like" oligomers: A common process in aqueous and ionic atmospheric particles?, Geophys. Res. Lett., 34(21), L21812, doi:10.1029/2007GL031300, 2007.

Nozière, B., Dziedzic, P., and Cordova, A.: Products and Kinetics of the Liquid-Phase Reaction of Glyoxal Catalyzed by Ammonium Ions $\left(\mathrm{NH}_{4}^{+}\right)$, J. Phys. Chem. A, 113(1), 231-237, 2009a.

Nozière, B., Dziedzic, P., and Córdova, A.: Common inorganic ions are efficient catalysts for organic reactions in atmospheric aerosols and other natural environments, Atmos. Chem. Phys. Discuss., 9, 1-21, 2009b, http://www.atmos-chem-phys-discuss.net/9/1/2009/.

Peltier, R. E., Sullivan, A. P., Weber, R. J., Wollny, A. G., Holloway, J. S., Brock, C. A., deGouw, J. A., and Atlas, E. L.: No evidence 
for acid-catalyzed secondary organic aerosol formation in power plant plumes over metropolitan Atlanta, Georgia, Geophys. Res. Lett., 34, L06801, doi:10.1029/2006GL028780, 2007.

Pszenny, A. A. P., Moldanová, J., Keene, W. C., Sander, R., Maben, J. R., Martinez, M., Crutzen, P. J., Perner, D., and Prinn, R. G.: Halogen cycling and aerosol $\mathrm{pH}$ in the Hawaiian marine boundary layer, Atmos. Chem. Phys., 4, 147-168, 2004, http://www.atmos-chem-phys.net/4/147/2004/.

Rosen, S.: Fundamental Principles of Polymeric Materials, 2nd Edn., Wiley-Interscience, 1993.

Salma, I., Ocskay, R., Varga, I., and Maenhaut, W.: Surface tension of atmospheric humic-like substances in connection with relaxation, dilution, and solution $\mathrm{pH}$, J. Geophys. Res.-Atmos., 111(D23), D23205, doi:10.1029/2005JD007015, 2006.

Setschenow, J. Z.: Uber die Konstitution der Salzosungen auf Grund ihres Verhaltens zu Kohlensaure, Z. Phys. Chem., 4, 117$125,1889$.

Surratt, J. D., Kroll, J. H., Kleindienst, T. E., Edney, E. O., Claeys, M., Sorooshian, A., Ng, N. L., Offenberg, J. H., Lewandowski, M., Jaoui, M., Flagan, R. C., and Seinfeld, J. H.: Evidence for organosulfates in secondary organic aerosol, Environ. Sci. Technol., 41(2), 517-527, 2007.

Surratt, J. D., Gomez-Gonzalez, Y., Chan, A. W. H., Vermeylen, R., Shahgholi, M., Kleindienst, T. E., Edney, E. O., Offenberg, J. H., Lewandowski, M., Jaoui, M., Maenhaut, W., Claeys, M., Flagan, R. C., and Seinfeld, J. H.: Organosulfate formation in biogenic secondary organic aerosol, J. Phys. Chem. A, 112(36), 8345-8378, 2008.

Tabazadeh, A.: Organic aggregate formation in aerosols and its impact on the physicochemical properties of atmospheric particles, Atmos. Environ., 39(30), 5472-5480, 2005.

Tang, I. N.: Thermodynamic and optical properties of mixed-salt aerosols of atmospheric importance, J. Geophys. Res.-Atmos., 102(D2), 1883-1893, 1997.

Tang, I. N. and Munkelwitz, H. R.: Water Activities, Densities, and Refractive-Indexes of Aqueous Sulfates and Sodium-Nitrate Droplets of Atmospheric Importance, J. Geophys. Res.-Atmos., 99(D9), 18801-18808, 1994.

Tang, I. N., Tridico, A. C., and Fung, K. H.: Thermodynamic and optical properties of sea salt aerosols, J. Geophys. Res.-Atmos., 102(D19), 23269-23275, 1997.

Thornalley, P. J., Langborg, A., and Minhas, H. S.: Formation of glyoxal, methylglyoxal, and 3-deoxyglucosone in the glycation of proteins by glucose, Biochem. J., 344, 109-116, 1999.

Tong, C. H., Blanco, M., Goddard, W. A., and Seinfeld, J. H.: Secondary organic aerosol formation by heterogeneous reactions of aldehydes and ketones: A quantum mechanical study, Environ. Sci. Technol., 40(7), 2333-2338, 2006.
Tuazon, E. C., Atkinson, R., Macleod, H., Biermann, H. W., Winer, A. M., Carter, W. P. L., and Pitts, J. N.: Yields of Glyoxal and Methylglyoxal from the $\mathrm{NO}_{\mathrm{x}}$-Air Photooxidations of Toluene and $\mathrm{m}$-Xylene and p-Xylene, Environ. Sci. Technol., 18(12), 981-984, 1984.

Tuazon, E. C., Macleod, H., Atkinson, R., and Carter, W. P. L.: Alpha-Dicarbonyl Yields from the NOx-Air Photooxidations of a Series of Aromatic-Hydrocarbons in Air, Environ. Sci. Technol, 20(4), 383-387, 1986.

Tuazon, E. C., Aschmann, S. M., Nishino, N., Arey, J., and Atkinson, R.: Kinetics and products of the $\mathrm{OH}$ radical-initiated reaction of 3-methyl-2-butenal, Phys. Chem. Chem. Phys., 7(11), 2298-2304, 2005.

Tunca, A. A., Sirkecioglu, O., Talinli, N., and Akar, A.: Condensation Polymers from Diphenols and Glyoxal, Euro. Polym. J., 31(1), 9-14, 1995.

Vijay, D. and Sastry, G. N.: Relative energies of $\mathrm{C}_{2} \mathrm{O}_{2} \mathrm{H}_{2}$ isomers and their ionized counterparts: possibility of bond stretch isomerism, J. Mol. Struct., 714, 199-207, 2005.

Volkamer, R., Platt, U., and Wirtz, K.: Primary and secondary glyoxal formation from aromatics: Experimental evidence for the bicycloalkyl-radical pathway from benzene, toluene, and pxylene, J. Phys. Chem. A, 105(33), 7865-7874, 2001.

Volkamer, R., Molina, L. T., Molina, M. J., Shirley, T., and Brune, W. H.: DOAS measurement of glyoxal as an indicator for fast VOC chemistry in urban air, Geophys. Res. Lett., 32(8), L08806, doi:10.1029/2005GL022616, 2005.

Volkamer, R., Jimenez, J. L., San Martini, F., Dzepina, K., Zhang, Q., Salcedo, D., Molina, L. T., Worsnop, D. R., and Molina, M. J.: Secondary organic aerosol formation from anthropogenic air pollution: Rapid and higher than expected, Geophys. Res. Lett., 33(17), L17811, doi:10.1029/2006GL026899, 2006.

Volkamer, R., San Martini, F., Molina, L. T., Salcedo, D., Jimenez, J. L., and Molina, M. J.: A missing sink for gas-phase glyoxal in Mexico CIty: Formation of secondary organic aerosol, Geophys. Res. Lett., 34, L19807, doi:10.1029/2007GL030752, 2007.

Volkamer, R., Ziemann, P. J., and Molina, M. J.: Secondary Organic Aerosol Formation from Acetylene $\left(\mathrm{C}_{2} \mathrm{H}_{2}\right)$ : seed effect on SOA yields due to organic photochemistry in the aerosol aqueous phase, Atmos. Chem. Phys., 9, 1907-1928, 2009, http://www.atmos-chem-phys.net/9/1907/2009/.

Wilke, C. R. and Chang, P.: Correlation of diffusion coefficients in dilute solutions, AIChE J., 1(2), 264-270, 1955. 